\title{
High removal efficiency of dye pollutants by anodic Fenton treatment
}

\author{
V. Rondán ${ }^{1}$, B. Ramírez ${ }^{1}$, S. Silva-Martínez ${ }^{2}$, J.A. Hernández ${ }^{2}$, Manoj Kumar Tiwari3, \\ A. Alvarez-Gallegos, ${ }^{2, *}$ \\ ${ }^{1}$ Posgrado en Ingeniería y Ciencias Aplicadas FCQeI-CIICAp, UAEM, Morelos. \\ ${ }^{2}$ Centro de Investigación en Ingeniería y Ciencias Aplicadas. UAEM, Av. Universidad 1001, \\ Cuernavaca Morelos, 62209. México. Tel/Fax: (777) 3297084 and 329777984. \\ ${ }^{3}$ School of Water Resources, Indian Institute of Technology Kharagpur, Kharagpur - 721302, INDIA \\ *E-mail: aalvarez@uaem.mx
}

doi: $10.20964 / 2020.01 .21$

Received: 4 August 2019 / Accepted: 12 October 2019 / Published: 30 November 2019

\begin{abstract}
Anodic Fenton treatment (AFT) has been extensively applied for water remediation. In general, three different bench-scale divided (salt bridge or ion membrane) reactors have been focused to treat small volumes $(90-350 \mathrm{~mL})$ and low concentration $(20-400 \mu \mathrm{M})$ of organic pollutants in short treatment periods (2-40 $\mathrm{min}$ ). The best experimental condition of AFT was found by performing several trails with different $\mathrm{H}_{2} \mathrm{O}_{2}$ concentrations continuously added. In this work a modified AFT reactor is proposed: a divided electrochemical flow cell $\left(7.58 \times 10^{-3} \mathrm{~m} \mathrm{~s}^{-1}\right)$ separating the catholyte from the anolyte by a treated cation permeable membrane. This electrochemical process has been focused to treat $2 \mathrm{~L}$ of aqueous solutions of $1 \mathrm{mM}$ acid orange 7 (AO7), $0.5 \mathrm{mM}$ methylene blue (MB), and $0.12 \mathrm{mM}$ reactive black 5 (RB5). The stoichiometric amount of $\mathrm{H}_{2} \mathrm{O}_{2}$ required was added in a single dose at the beginning of the electrolysis. At $40 \mathrm{~min}$ of electrolysis, a near complete discoloration of all dye solutions and COD reductions of $85 \%, 84 \%$ and $76 \%$ for $\mathrm{AO} 7, \mathrm{MB}$ and $\mathrm{RB} 5$ were obtained, respectively. Additionally, an industrial textile effluent (300 ppm COD) was successfully oxidized in 40 minutes of electrolysis, lowering $95 \%$ of the initial COD using the proposed AFT reactor. The energy requirements were low for the treatment of all the synthetic dye solutions $\left(\leq 0.041 \mathrm{~kW} \mathrm{~h} \mathrm{~m}^{-3}\right)$ and for the oxidation of the industrial wastewater $\left(0.075 \mathrm{~kW} \mathrm{~h} \mathrm{~m}^{-3}\right)$. Furthermore, the AFT electrochemical reactor allows an economic cogeneration of $\mathrm{H}_{2}\left(19.85 \mathrm{~kW} \mathrm{~h} \mathrm{~kg}^{-1} \mathrm{H}_{2}\right)$ together with the treatment of textile effluents.
\end{abstract}

Keywords: Anodic Fenton treatment; Azo dyes; Catalytic $\mathrm{H}_{2} \mathrm{O}_{2}$ activation; $\mathrm{H}_{2}$ production; Textile industry wastewater

$\underline{\text { FULL TEXT }}$ 
(C) 2020 The Authors. Published by ESG (www.electrochemsci.org). This article is an open access article distributed under the terms and conditions of the Creative Commons Attribution license (http://creativecommons.org/licenses/by/4.0/). 